\title{
DESCRIPTION AND DISTRIBUTION OF NEMACYSTUS HOWEI (W.R. TAYLOR) KYLIN (CHORDARIACEAE) FROM THE NORTHERN COAST OF THE YUCATÁN PENINSULA \\ DESCRIPCIÓN Y DISTRIBUCIÓN DE NEMACYSTUS HOWEI (W.R. TAYLOR) KYLIN (CHORDARIACEAE) EN LA COSTA NORTE DE LA PENÍNSULA DE YUCATÁN
}

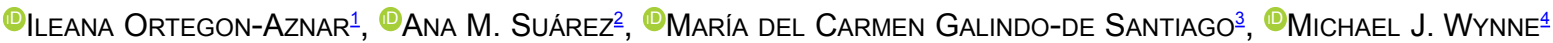

\author{
1Departamento de Biología Marina, UADY, Itzimna Mérida, Yucatán. México \\ ${ }^{2}$ Centro de Investigaciones Marinas, UH, La Habana, Cuba. \\ ${ }^{3}$ UMDI-Sisal, Facultad de Ciencias, UNAM/Escuela Nacional de Estudios Superiores-Unidad Mérida, UNAM, Yucatán, México \\ ${ }^{4}$ Department of Ecology and Evolutionary Biology and Herbarium, University of Michigan, Ann Arbor, MI, USA.
}

*Corresponding author: oaznar@correo.uady.mx

\begin{abstract}
Background: There are few studies about Nemacystus on the Atlantic coast, and N. howei has been reported only once for Mexico; that record, however, did not provide a description of this species.

Question: What are the morphological characteristics of Nemacystus howei and its distribution on the Yucatan coast?

Species study: Macroalgae, Phaeophyceae, Nemacystus howei.

Study site and year of study: North coast of Yucatán Peninsula of Mexico. Dry and rainy seasons from 2017 to 2019.

Methods: Sampling was carried out at five localities, at 5 and $10 \mathrm{~m}$ depths, with scuba equipment. Specimens were preserved in diluted formalin in sea water; silica gel and dried-pressed vouchers are housed at the UADY

Results: Six samples were collected at the five localities. Each one contains a small mass of filamentous of specimens of Nemacystus howei, that were found only during dry season, at both depths sampled. This alga has a thallus of an entangled filamentous mass of cylindrical, mucilaginous axes, of a light brown color. Younger branches have a solid central axis. Branching is abundant. The main, older axes are hollow. The assimilatory filaments are branched a few times, producing uniseriate colorless hairs and with plurilocular sporangia arising from the base. Nemacystus howei is easily confused with Cladosiphon occidentalis Kylin due to their similar morphology, branching pattern, and size.

Conclusion: The significant morphological similarities between these species as well as the paucity of specific works on the Phaeophyceae of the Yucatan Peninsula may explain why Nemacystus howei had not been previously reported.
\end{abstract}

Keywords: Cladosiphon, Gulf of Mexico, morphology, Phaeophyceae.

\section{Resumen}

Antecedentes: Nemacystus es un género poco estudiado y N. howei solo se ha reportado una vez para México, sin una descripción de esta especie.

Pregunta: ¿Cuáles son las características morfológicas de Nemacystus howei y su distribución en la costa de Yucatán?

Especie de estudio: Macroalgas, Phaeophyceae, Nemacystus howei.

Sitio y años de estudio: Costa norte de la península de Yucatán. Temporadas de secas y lluvias, de 2017 a 2019.

Métodos: Se muestrearon 5 sitios a lo largo de la costa a 5 y 10 metros de profundidad, con equipo de buceo autónomo. Los especímenes se conservaron en formalina al $4 \%$, sílica gel y en cartulina y se depositaron en el herbario de la UADY Mérida.

Resultados: Se colectaron 6 muestras en cinco localidades cada una contenía unos filamentos de especímenes de Nemacystus howei. Solo se encontró durante la época de seca, a ambas profundidades. Se presenta como una masa de filamentos cilíndricos, y mucilaginosos, de color café claro. Los ejes principales son huecos y las ramas juveniles tienen eje central sólido. La ramificación es abundante. Los filamentos asimiladores son poco ramificados, producen pelos incoloros uniseriados y la esporangia plurilocular surge de su base. Nemacystus howei, se confunde fácilmente con Cladosiphon occidentalis Kylin, debido a su morfología, patrón de ramificación y tamaño similares.

Conclusión: Se considera que, por la gran similitud morfológica con C. occidentalis y la falta de trabajos especializados sobre el grupo Phaeophyceae, es posible que por ello no se había reportado anteriormente para la Península de Yucatán.

Palabras claves: Cladosiphon, Golfo de México, morfología, Phaeophyceae. 
Nemacystus is a genus in the family Chordariaceae (Order Ectocarpales, Class Phaeophyceae) and contains 8 species (Guiry \& Guiry 2020). The type species of the genus is $N$. ramulosus Derbès \& Solier. There are relatively few studies on Nemacystus, the most complete one being that of de Jong \& Prud'homme (1997), who did a review of the genus based on morphological characters and presumed phylogenetic relationships. A molecular phylogeny, however, has not yet been carried out for this genus. Species differ from each other on such subtle morphological traits as the dimensions and shape of the assimilatory filaments, plurilocular sporangia, color, ramification, and general habit (Jong \& Prud'homme 1997).

In North America only two species have been reported, Nemacystus brandegeei (Setchell \& Gardner) Kylin on the Pacific coast (Pedroche et al. 2008, Norris 2010) and Nemacystus howei (W.R. Taylor) Kylin on the Atlantic coast. On the Atlantic coast $N$. howei has been reported and described from Florida, North Carolina, and Bermuda (Taylor 1928, 1960, Schneider \& Searles 1975, 1991, Schneider 2003). In Brazil, this species was recorded by Cassano \& Pedrini (1992), which was the first report for the Atlantic coast of South America. Menezes \& Campos de Paula (2010) later reported it from the southeastern coast of Brazil. It was reported and described from Florida by Taylor (1928, 1960) and Dawes \& Mathieson (2008); for North Carolina it was reported and described by Schneider \& Searles (1991), and for the Caribbean islands of Aruba and Bonaire by Vroman \& Stegenga (1988). For the Gulf of Mexico, Fredericq et al. (2009) reported N. howei as a synonym of "Eudesme howei" Taylor nom. inval., citing the report of Phillips \& Springer (1960) for the Gulf coast of Florida. Finally, for the Atlantic coast of Mexico, MateoCid et al. (2013) reported $N$. howei as a new record from the subtidal benthic macroalgae from the Campeche Banks.

Almost all the previous works with descriptions showed only illustrations of the species, especially of the assimilatory filaments and the plurilocular sporangia, except that of Cassano \& Pedrini (1992), which also included photos of transverse sections of the thallus, depicting the central axis to be solid in younger parts and hollow in older parts. For the Atlantic coast of Mexico, however, despite being the first report, a description of the morphological characteristics or figures of this species has not yet been given for Mexico. So, this report is the first morphological descriptive account of this species in Mexico, and we provide the distribution of Nemacystus howei for the northern coast of the Yucatan Peninsula.

\section{Materials and methods}

Sampling was carried out on the northern coast of Yucatan during the dry season (with a $26.6{ }^{\circ} \mathrm{C}$ temperature average, 38 UPS and $8.8 \mathrm{pH}$ ) and the rainy season (with a $29.4{ }^{\circ} \mathrm{C}$ temperature average, 36 UPS and $7.9 \mathrm{pH}$ ) at five localities: Ría Lagartos, $21^{\circ} 38^{\prime} 31.5^{\prime \prime} \mathrm{N}$; 88 $18^{\circ} 19.8^{\prime \prime} \mathrm{W}$,

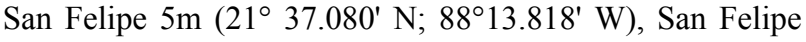
$10 \mathrm{~m}\left(21^{\circ} 39.344^{\prime} \mathrm{N} ; 88^{\circ} 16.344^{\prime} \mathrm{W}\right)$, Coloradas $10 \mathrm{~m}\left(21^{\circ}\right.$ 43' 17.2" N; 87 58' 187" W), Chicxulub $10 \mathrm{~m}\left(21^{\circ} 32.284^{\prime}\right.$ $\left.\mathrm{N} ; 89^{\circ} 30.973^{\prime} \mathrm{W}\right)$, “Bajos 10" $10 \mathrm{~m}\left(21^{\circ} 21.210 \mathrm{~N} ; 90^{\circ}\right.$ $09.125 \mathrm{~W})$ and "Bajos 10" $5 \mathrm{~m}\left(21^{\circ} 20.870 \mathrm{~N} ; 90^{\circ} 08.940\right.$ W.) at Sisal reefs (Figure 1) from 2017 to 2019 at two depths $(5$ and $10 \mathrm{~m})$ in the sublittoral, using SCUBA

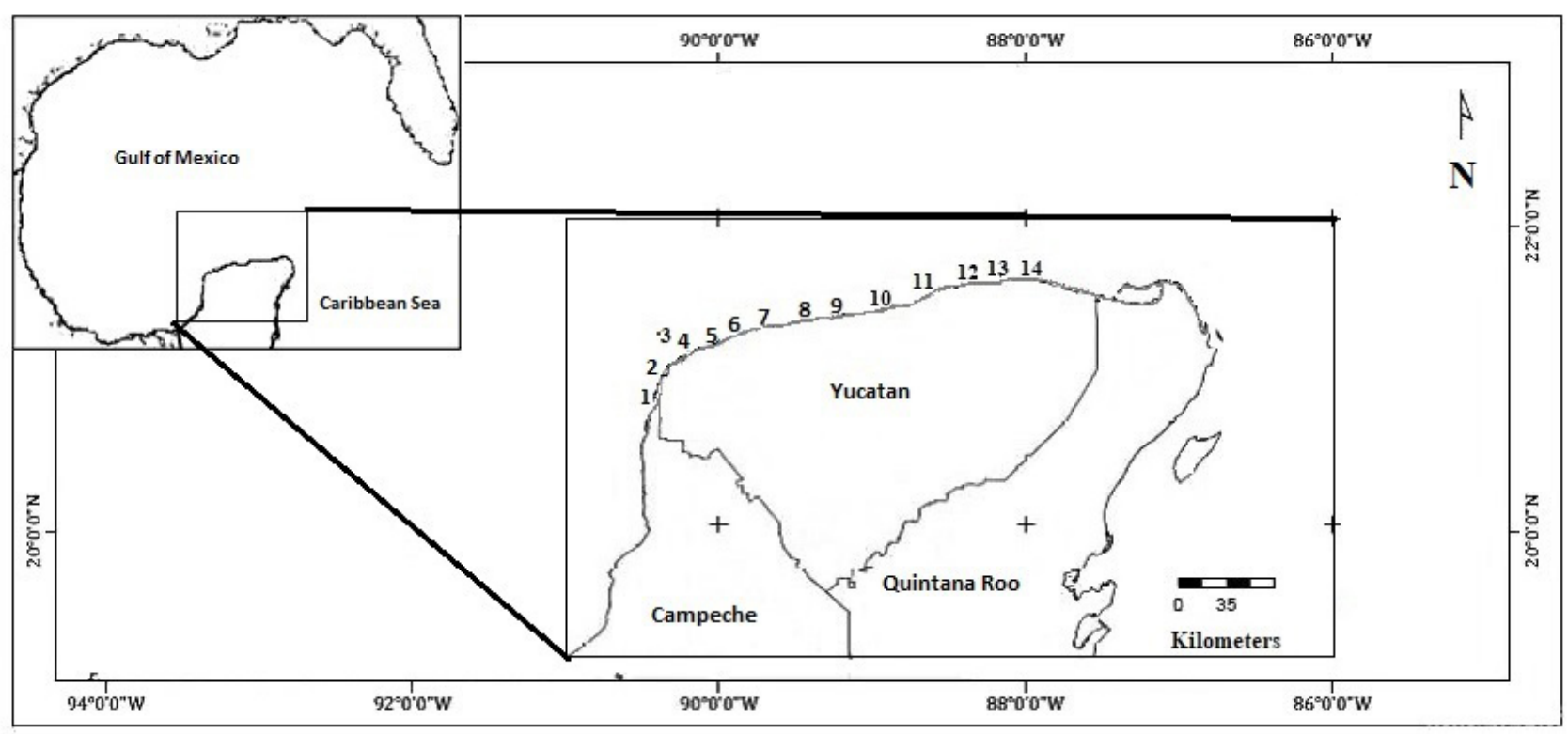

Figure 1. Sampling sites of Nemacystus howei: 1.- "Bajos de 10" (Sisal reefs),2.-Chicxulub, 3.-San Felipe, 4.-Rio Lagartos, 5.- Las Coloradas. Telchac was the locality where $N$. howei (reported as brandegei) was found at the UADY herbarium. 
equipment. Specimens were separated, labeled, and preserved in a $4 \%$ formaldehyde solution in seawater, silica gel and two dry vouchers were made from each sample, which are housed at the Herbarium Alfredo Barrera Marin of the University Autonomous of Yucatan (UADY). The determination was made using the keys and descriptions of Taylor (1960), Schneider \& Searles (1991), Cassano \& Pedrini (1992), and Dawes \& Mathieson (2008).

\section{Results}

Six samples were collected at the five localities and each one contains a small mass of filamentous specimens of the species Nemacystus howei (W.R. Taylor) Kylin 1940, that belongs to: Kingdom Chromista, Phylum Ochrophyta, Class Phaeophyceae, Order Ectocarpales, Family Chordariaceae, Genus Nemacystus Derbès \& Solier, 1850.

Basionym. Castagnea howei W.R. Taylor 1928: p. 111, Reported by Taylor 1960: p. 249, Earle 1969: p. 184, Dawes 1974: p. 107, Schneider \& Searles 1991: p.138, Dawes \& Mathieson 2008: p.145. Type locality: Dry Tortugas, Florida. Distribution in the Western Atlantic: The Carolinas, Florida, northern Gulf of Mexico, Gulf of Mexico, Brazil, Bermuda. Distribution on the northern coast of Yucatán Ría Lagartos, San Felipe, Coloradas, Chicxulub, and "Bajos 10" at Sisal reefs and Telchac (Figure 1). We observed N. howei to occur only in the dry season between March-June. It can be epiphytic or saxicolous, from 5 to $10 \mathrm{~m}$ depths (Table 1).

Examined Material. We collected six samples of specimens of Nemacystus howei (Table 1): UADY 1594 at Coloradas, UADY 1595 at Ría Lagartos, UADY 1596 at San Felipe, UADY 1597 at San Felipe, UADY 1598 at Chicxulub, UADY 1599 at "Bajos de 10" (Sisal Reefs).

Description. Thallus with a filamentous form, soft and mucilaginous entangled masses, up to $45 \mathrm{~cm}$ long, color light brown and somewhat greenish (Figure 2A-B). The axis is cylindrical, and the uniaxial structure is visible proximal to the apical cells. Branching is abundant, up to three orders, alternate to irregular. The internal structure is differentiated between a medulla (with 2-4 rows of colorless cells) and cortical cells. The main and older axes become hollow with a diameter between $0.3-0.6 \mathrm{~mm}$ (Figures 2C, $\underline{3 \mathrm{~A}}$ ); the younger branches have a solid central axis, thin, cylindrical and often entangled, $0.1-0.3 \mathrm{~mm}$ in diameter (Figure 3C). The medullary cells are from $55-120$ by $30-60 \mu \mathrm{m}$ in diameter. The cortical cells are $12-25$ by $12-45 \mu \mathrm{m}$ in diameter.
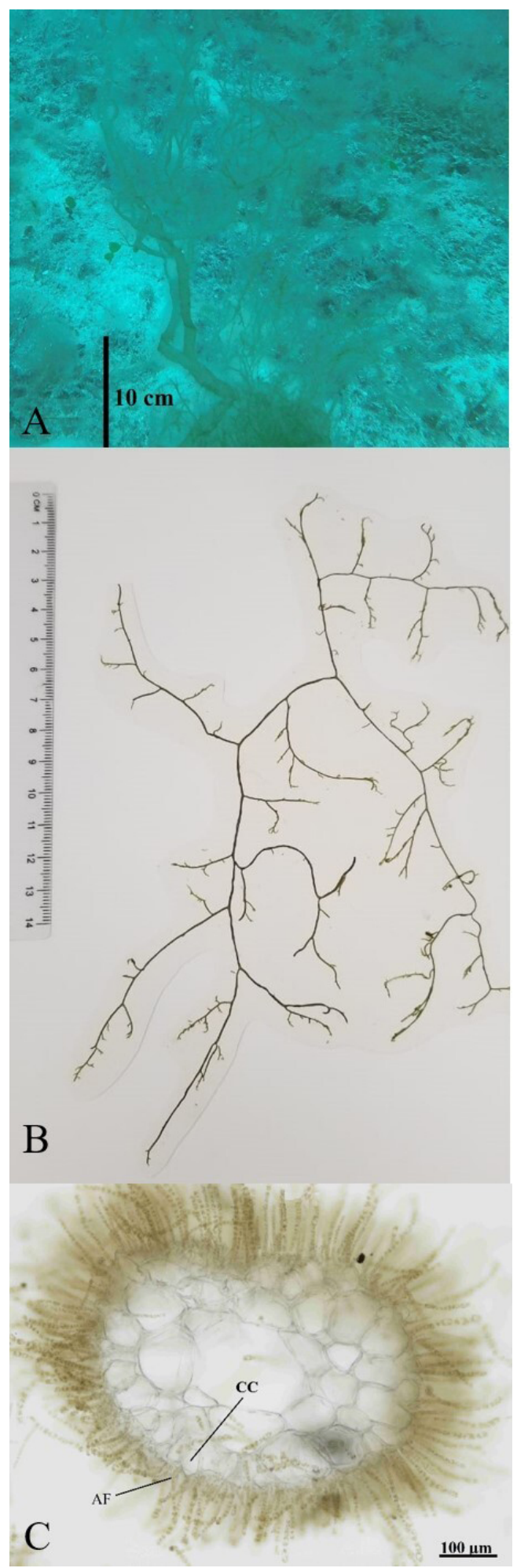

Figure 2. Nemacystus howei. A) Habit, B) A pressed specimen, C) Transverse section with cortical cells (CC) ramified assimilatory filaments (AF) and showing sporangia and a hollow interior. 
Table 1. Material examined.

\begin{tabular}{lllllc}
\hline Date & Localities & Genus & species & I.D Number & Depth (m) \\
\hline $\mathbf{0 6 / 0 5 / 2 0 1 7}$ & Coloradas & Nemacystus & howei & UADY 1594 & 10 \\
$\mathbf{0 6 / 0 5 / 2 0 1 7}$ & Ría Lagartos & Nemacystus & howei & UADY 1595 & 5 \\
$\mathbf{0 6 / 0 5 / 2 0 1 7}$ & San Felipe & Nemacystus & howei & UADY 1596 & 5 \\
$\mathbf{0 6 / 0 5 / 2 0 1 7}$ & San Felipe & Nemacystus & howei & UADY 1597 & 10 \\
$\mathbf{0 7 / 0 6 / 2 0 1 9}$ & Chicxulub & Nemacystus & howei & UADY 1598 & 10 \\
$\mathbf{1 5 / 0 6 / 2 0 1 9}$ & Bajos de 10 & Nemacystus & howei & UADY 1599 & 5 \\
$\mathbf{2 8 / 0 4 / 2 0 1 7}$ & Bajos de 10 & Cladosiphon & occidentalis & UADY 1593 & 10 \\
$\mathbf{1 7 / 1 0 / 2 0 1 0}$ & Telchac & Nemacystus & howei (reported as brandegeei) & UADY 1136 - (Epiphyte of Sargassum) \\
\hline
\end{tabular}

The assimilatory filaments are not branched, 6-8(-13) cells long, with rounded moniliform or reniform cells, $10-15 \mu \mathrm{m}$ near the apices and to $4-6 \mu \mathrm{m}$ below. There are several discoid plastids per cell. These cells produce colorless hairs, 8-10 $\mu \mathrm{m}$ in diameter (Figure 3C). Unilocular sporangia were not observed. Plurilocular sporangia are uniseriate, arising from the base of the assimilatory filaments or directly from the cortical cells; 40-80 $\mu \mathrm{m}$ long with 8-23 loculi, which are 4-6 $\mu \mathrm{m}$ in diameter (Figure 3D).
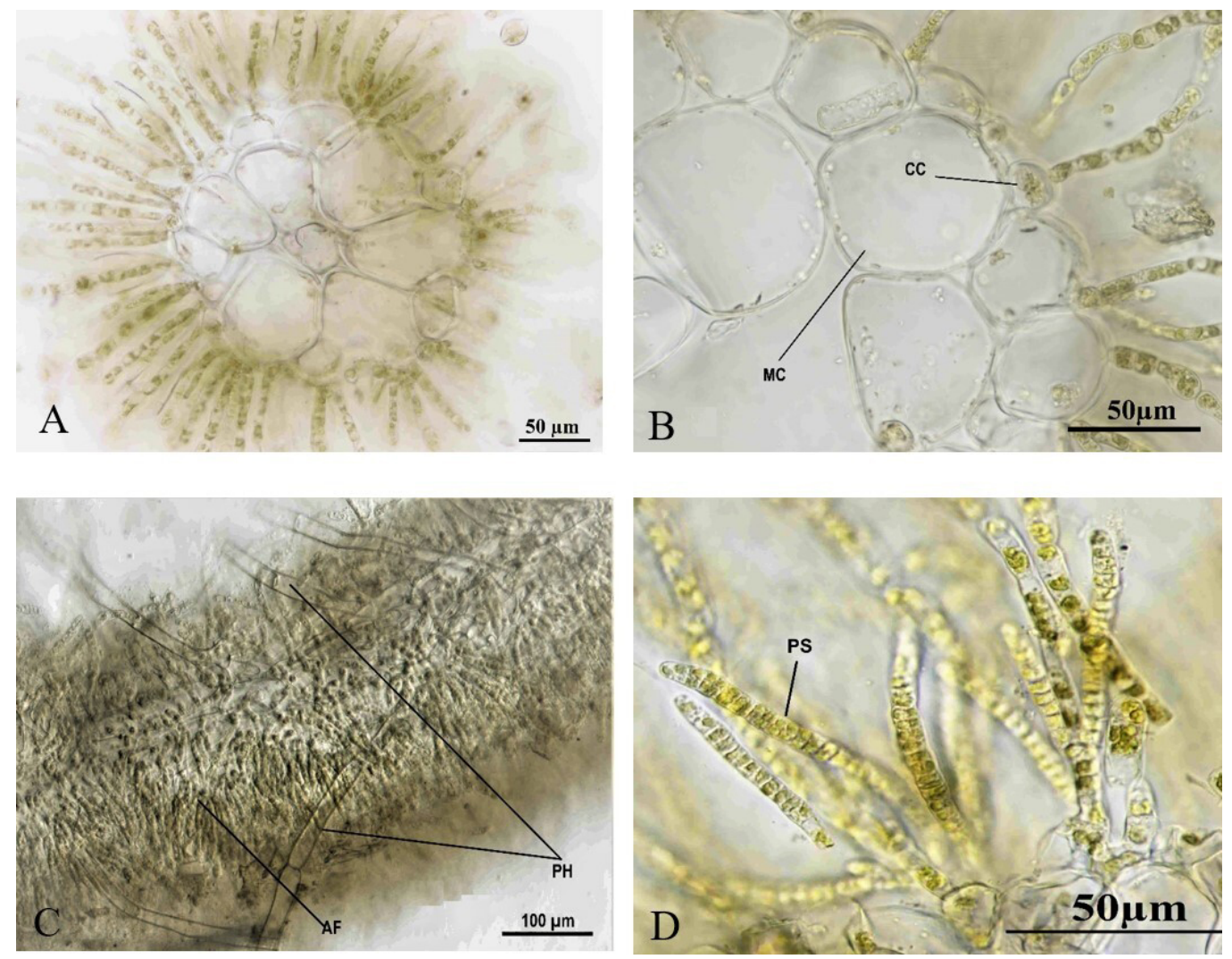

Figure 3. Nemacystus howei. A) Rows of medullary cells (MC) and cortical cells (CC), B) Transverse section showing a solid axis, C) Phaeophycean hairs (PH) and assimilatory filaments (AF), D) Plurilocular sporangia (PS). 

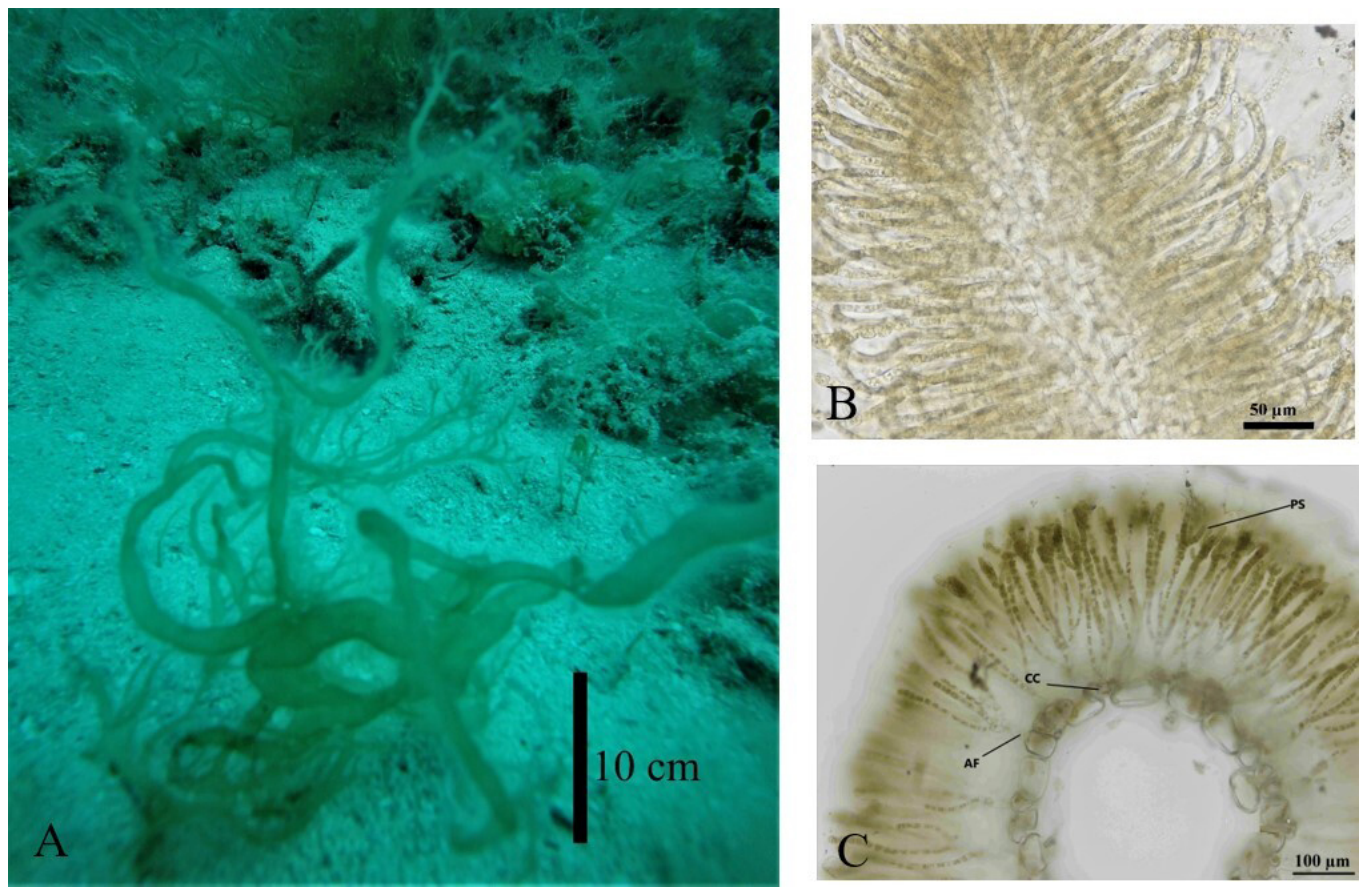

Figure 4. Cladosiphon occidentalis. A) Habit, B) Branch, C) Transverse section of C. occidentalis with cortical cells (CC) ramified assimilatory filaments (AF) and plurilocular sporangia (PS).

approximately $45 \mathrm{~cm}$, which is like our specimens, and with a diameter similar to those values for North Carolina specimens, as reported by Schneider \& Searles (1991), who found specimens to be slender with main axes not exceeding a diameter of $0.5 \mathrm{~mm}$. Also, our specimens were found at lower depths than other reports (Table 2 in Appendix 1).

Nemacystus howei (Figure 2A, 3C) has often been misidentified and easily confused with Cladosiphon occidentalis Kylin (Kylin 1940, Schneider \& Searles 1975, de Jong \& Prud'homme 1997) because of their very similar external morphology, ramification, and size (Figure 4A-B).

We found C. occidentalis (UADY 1593) at one locality ("Bajos de 10" at Sisal Reef) (Table 1), and it was necessary to make transverse sections to verify the identity. The main differences are the solid medulla of the younger branches and more medullary cells in the older branches of $N$. howei, whereas the cortex in C. occidentalis is formed of only one row of cells. The assimilatory filaments in $C$. occidentalis have a pedicel and then bifurcate two or three times; also, the sporangia are formed at the end of the filaments (Figure 4C), whereas in $N$. howei the filaments are uniseriate and the sporangia arise at the base of the filaments or directly on the cortical cells (Figure 3A).

At the UADY herbarium we found a single collection that had been identified as $N$. brandegeei (Setchell \&
Gardner) Kylinin Telchac, Yucatan (Figure 1), but it was misidentified and turned out to be $N$. howei (Table 1). There were no vouchers of Cladosiphon besides the ones that we collected.

Even though the external morphologies of these two species are very similar, it is relatively easy to distinguish them when their internal characteristics are checked. Their external resemblances have likely resulted in past confusion in their accurate determinations. Also, the paucity of specific works on the Phaeophyceae for the Yucatan Peninsula is another probable explanation why this is the first report of $N$. howei for the Yucatan Peninsula.

\section{Acknowledgments}

We express our gratitude to the Universidad Nacional Autónoma de México which supported the Program for Projects for the Innovation and Improvement of Education PAPIME PE207317, which enabled us to carry out this project. Also, our thanks to Dr. Xavier Chiappa Carrara, Chairman of the scientific network RECORECOS (Red para el Conocimiento de los Recursos Costeros del Sureste) for supporting logistics. Finally, we thank Dr. Armin Tuz, M.Sc. Johnny Valdez, and the students Mariana Álvarez, Fernando Ayuso, Valery Ávila, and Karla Durán for their support in the field. 


\section{Literature cited}

Cassano V, Pedrini AG. 1993. Nemacystus howei (Taylor) Kylin (Phaeophyta, Spermatochnaceae): nova referéncia para a flora marinha Atlántica Sul-Americana. Hoehnea 20: 93-100.

Dawes CJ, 1974. Algae of the West Coast of Florida. USA: University of Miami Press. ISBN-10:9780870242588

Dawes CJ, Mathieson AC. 2008. The seaweeds of Florida. Florida: University Press of Florida. ISBN: 978-0-8130-3148-4

Earle SA. 1969. Phaeophyta of the eastern Gulf of Mexico. Phycologia 7: 71-254. DOI: https://doi.org/10.2216/ i0031-8884-7-2-71.1

Fredericq S, Cho TO, Earle SA, Gurgel CF Krayesky DM Mateo-Cid LE, Mendoza-González AC, Norris JN, Suárez AM. 2009. Seaweeds of the Gulf of Mexico, In: Felder D.L, D.K. Camp, eds. Gulf of Mexico-Origins, Waters, and Biota. I. Biodiversity. Texas: Texas A\&M Press, pp. 187-259. ISBN-13: 978-1603440943

Guiry MD, Guiry, GM. 2020. AlgaeBase. World-wide electronic publication, National University of Ireland, Galway. http://www.algaebase.org (accessed April 14, 2020).

Jong YSDM de, Prud'homme van Reine WF. 1997. A review of the genus Nemacystus (Spermatochnaceae, Chordariales, Phaeophyceae), including phylogenetic and biogeographical hypothesis. Nova Hedwigia 64: $1-40$.

Kylin H. 1940. Die Phaeophyceenordnung Chordariales. Acta Universitatis Lundensis 36: 1-67.

Mateo-Cid LE, Mendoza-González C, Fredericq S. 2013. Lista de algas marinas submareales de los bancos de Campeche, México. Acta Botanica Venezuelica 36: 95-108. DOI: https://doi.org/10.21829/abm104.2013.57

Menezes Széchy MT, Campos de Paula J. 2010. Phaeophyceae. In: Forzza RC, ed. Catálogo de Plantas e Fungos do Brasil. Vol. 1. Rio de Janeiro: Andrea
Jakobsson Estúdio; Instituto de Pesquisas Jardim Botânico do Rio de Janeiro, pp. 404-408. ISBN: 978-85-88742-42-0.

Norris JN. 2010. Marine algae of the Northern Gulf of California: Chlorophyta and Phaeophyceae. Smithsonian Contributions to Botany 94: 1-276. DOI: https://doi.org/ $\underline{\text { 10.5479/si.0081024X.94.276 }}$

Pedroche PF, Silva PC, Aguilar Rosas LE, Dreckmann KM, Aguilar Rosas R. 2008. Catálogo de las algas benthónicas del Pacifico de México II. Phaeophycota. México, D.F: Universidad Autónoma Metropolitana. ISBN: 978-970-31-0909-8

Phillips RC, Springer VG. 1960. Observations on the offshore benthic flora in the Gulf of Mexico off Pinellas County, Florida. American Midland Naturalist 64: 362-381. DOI: https://doi.org/10.2307/2422669

Schneider CW. 2003. An annotated checklist and bibliography of the marine macroalgae of the Bermuda Islands. Nova Hedwigia 76: 275-361. DOI: https:// doi.org/10.1127/0029-5035/2003/0076-0275

Schneider CW, Searles RB. 1975. North Carolina marine algae, IV. Further contribution from the continental shelf, including two new species of Rhodophyta. Nova Hedwigia 26:83-103.

Schneider CW, Searles RB. 1991. Seaweeds of the southeastern United States. Cape Hatteras to Cape Canaveral. Durham \& London: Duke University Press. ISBN: 0-8223-1101-1.

Taylor WR. 1928. The marine algae of Florida with special reference to the Dry Tortugas. USA: Publications of the Carnegie Institution of Washington.

Taylor WR. 1960. Marine algae of the eastern tropical and subtropical coasts of the Americas. Ann Arbor: The University of Michigan Press.

Vroman M, Stegenga H. 1988. An annotated checklist of the marine algae of the Caribbean islands of Aruba and Bonaire. Nova Hedwigia 46: 433-480.

\footnotetext{
Associate editor: Ivón Mercedes Ramírez Morillo

Authors contribution: IOA Writing paper, analyzing data, field work, specimen's examination, taxonomic review, taxonomic determination. AMS specimens examination, taxonomic review, taxonomic determination, writing analysis, reviewing paper. MCGS field work, writing analysis and compilation of the database, reviewing paper. MJW Taxonomic review and nomenclature, herbarium review of the type specimen, reviewing paper.
} 
Appendix 1. Morphological characters of Nemacystus howei by different authors.

\begin{tabular}{|c|c|c|c|c|c|c|}
\hline & $\underline{\text { Taylor } 1960}$ & $\begin{array}{l}\text { Schneider \& } \\
\underline{\text { Searles } 1991}\end{array}$ & $\frac{\text { Cassano \& Pedrini }}{\underline{1992}}$ & $\begin{array}{c}\underline{\text { Jong \& }} \\
\underline{\text { Prud'homme } 1997}\end{array}$ & $\frac{\underline{\text { Dawes \& }}}{\underline{\text { Mathieson }}}$ & $\begin{array}{c}\text { Ortegon-Aznar et al. } \\
\text { this work }\end{array}$ \\
\hline Habit & $\begin{array}{l}\text { Entangled } \\
\text { with other } \\
\text { algae }\end{array}$ & $\begin{array}{l}\text { In tangled } \\
\text { masses }\end{array}$ & $\begin{array}{l}\text { Filamentous, twisted } \\
\text { and matted with } \\
\text { other algae. }\end{array}$ & $\begin{array}{l}\text { Much entangled. dark } \\
\text { brown }\end{array}$ & $\begin{array}{l}\text { Attached by a } \\
\text { rhizoidal } \\
\text { holdfast, } \\
\text { epiphytic, } \\
\text { entangled or on } \\
\text { limestone }\end{array}$ & $\begin{array}{l}\text { Filamentous, twisted } \\
\text { and matted with other } \\
\text { algae. }\end{array}$ \\
\hline Depth (m) & $7-55$ & $15-25$ & - & $\begin{array}{c}\text { Bermuda: 54-64, } \\
\text { Florida: 7.2-34.2, } \\
\text { North Carolina: } \\
\text { 15-25. }\end{array}$ & $13-55$ & $5-10$ \\
\hline Distribution months & - & $\begin{array}{l}\text { May-August, } \\
\text { November. }\end{array}$ & October- December & - & - & March-June \\
\hline Size $(\mathrm{cm})$ & $20-40$ & 40 & 35 & $20-50$ & 40 & $20-45$ \\
\hline Branches ramification & $\begin{array}{l}\text { Alternate } \\
\text { abundant }\end{array}$ & $\begin{array}{c}\text { Alternate } \\
\text { abundant, to } 3 \\
\text { orders }\end{array}$ & $\begin{array}{l}\text { Irregular abundant } \\
\text { rarely alternate }\end{array}$ & $\begin{array}{l}\text { Abundant irregular, } \\
\text { occasionally } \\
\text { dichotomous, } \\
\text { Alternate to } 3 \text { orders }\end{array}$ & $\begin{array}{l}\text { Alternate to } \\
\text { irregular } \\
\text { abundant, to } 3 \\
\text { orders }\end{array}$ & $\begin{array}{l}\text { Alternate to irregular } \\
\text { abundant, to } 3 \text { orders }\end{array}$ \\
\hline Cortex & - & - & $\begin{array}{l}\text { Solid at apical zones } \\
\text { and hollow in } \\
\text { intermediate part }\end{array}$ & $\begin{array}{l}\text { Central axis solid, } \\
\text { hollow in older } \\
\text { portions }\end{array}$ & - & $\begin{array}{c}\text { Solid at apical zones } \\
\text { and hollow in older } \\
\text { parts }\end{array}$ \\
\hline Cortex diameter $(\mathrm{mm})$ & $0.3-1$ & to 1 & - & $0.3-1$ & to 1 & $0.3-.06$ \\
\hline $\begin{array}{l}\text { Medullar cells }(\mu \mathrm{m}) \\
\text { wide by long }\end{array}$ & $\begin{array}{l}58-166 \times \\
132-1410\end{array}$ & $\begin{array}{l}30-166 \text { by } \\
132-1410\end{array}$ & $48-91$ by $26.5-60$ & $30-166$ by $132-1410$ & $\begin{array}{l}60-170 \text { by } \\
130-1400\end{array}$ & $55-120$ by $30-60$ \\
\hline $\begin{array}{l}\text { Cortical cells }(\mu \mathrm{m}) \\
\text { wide by long }\end{array}$ & - & - & $19-39$ by $12-27$ & $22 \times 14$ & - & $12-25$ by $12-45$ \\
\hline $\begin{array}{l}\text { Assimilatory filaments } \\
\text { Shape }\end{array}$ & $\begin{array}{l}\text { Cylindrical } \\
\text { below } \\
\text { moniliform or } \\
\text { reniform } \\
\text { above } \\
\text { unbranched }\end{array}$ & $\begin{array}{l}\text { Cylindrical } \\
\text { below } \\
\text { moniliform or } \\
\text { reniform } \\
\text { above - }\end{array}$ & $\begin{array}{l}\text { Cylindrical, } \\
\text { moniliform to } \\
\text { reniform } \\
\text { Simple to } \\
\text { branched }\end{array}$ & $\begin{array}{l}\text { Cylindrical } \\
\text { below } \\
\text { moniliform or } \\
\text { reniform above. } \\
\text { Simple, in small } \\
\text { bundles at the } \\
\text { base (Branched } \\
\text { at the base) }\end{array}$ & $\begin{array}{l}\text { rounded cells } \\
\text { unbranched }\end{array}$ & $\begin{array}{l}\text { Rounded } \\
\text { moniliform or } \\
\text { reniform } \\
\text { Unbranched or } \\
\text { rarely branched }\end{array}$ \\
\hline $\begin{array}{l}\text { Assimilatory } \\
\text { filaments } \\
\text { Number of cells } \\
\text { long }\end{array}$ & 8 & $8-13$ & (6-) 8-12 (-16) & $(6-) 7-9(-12)$ & $8-13$ & $6-8(-13)$ \\
\hline $\begin{array}{l}\text { Assimilatory filaments } \\
\text { Size diam }(\mu \mathrm{m})\end{array}$ & $\begin{array}{l}10-16.5 \\
\text { toward their } \\
\text { summits } 3.2-8 \\
\text { toward the } \\
\text { bases }\end{array}$ & $\begin{array}{l}\text { 10-17 near } \\
\text { apices }\end{array}$ & 12-26 apical cell & 16-19 apical cell & $\begin{array}{l}\text { 10-15 apical } \\
\text { cells }\end{array}$ & 10-15 apical cells \\
\hline
\end{tabular}


Nemacystus howei (W.R. Taylor) Kylin from the Yucatan Peninsula

\begin{tabular}{|c|c|c|c|c|c|c|}
\hline & $\underline{\text { Taylor } 1960}$ & $\begin{array}{l}\text { Schneider \& } \\
\underline{\text { Searles } 1991}\end{array}$ & $\frac{\text { Cassano \& Pedrini }}{\underline{1992}}$ & $\begin{array}{c}\underline{\text { Jong \& }} \\
\text { Prud'homme } 1997 \\
\end{array}$ & $\frac{\underline{\text { Dawes \& }}}{\text { Mathieson }}$ & $\begin{array}{l}\text { Ortegon-Aznar et al. } \\
\text { this work }\end{array}$ \\
\hline $\begin{array}{l}\text { Sporangia Plurilocular } \\
\text { Shape }\end{array}$ & - & $\begin{array}{l}\text { Uniseriate-bi } \\
\text { seriate }\end{array}$ & $\begin{array}{c}\text { Single, rarely } \\
\text { branched, straight or } \\
\text { curved, with pedicel }\end{array}$ & $\begin{array}{c}\text { Single or branching } \\
\text { pedicel or without } \\
\text { pedicel }\end{array}$ & $\begin{array}{l}\text { Uniseriate-bi } \\
\text { seriate, Single } \\
\text { or branching } \\
\text { pedicel }\end{array}$ & $\begin{array}{c}\text { Single, rarely } \\
\text { branched, straight or } \\
\text { curved, }\end{array}$ \\
\hline $\begin{array}{l}\text { Sporangia size long } \\
(\mu \mathrm{m})\end{array}$ & & $37-68$ & $29-77$ & $30-80$ & $40-80$ & $40-80$ \\
\hline $\begin{array}{l}\text { No of sporangia per } \\
\text { fascicle }\end{array}$ & to 10 & to 10 & to 15 & to 10 & to 6 & To 6 \\
\hline $\begin{array}{l}\text { Sporangia Size diam } \\
(\mu \mathrm{m})\end{array}$ & $6.6-7.5$ & $6-8$ & $5-7$ & $4.6-8.3$ & $6-8$ & $4-6$ \\
\hline Loculi & - & - & - & $8-20$ & - & $8-23$ \\
\hline $\begin{array}{l}\text { Unilocular sporangia } \\
\text { Shape }\end{array}$ & $\begin{array}{l}\text { Spherical to } \\
\text { ovoid }\end{array}$ & $\begin{array}{l}\text { Spherical to } \\
\text { ovoid }\end{array}$ & Spherical to ovoid & $\begin{array}{l}\text { Spherical to oval } \\
\text { regular or } \\
\text { asymmetrical }\end{array}$ & ovoid & - \\
\hline $\begin{array}{l}\text { Unilocular sporangia } \\
\text { size }(\mu \mathrm{m})\end{array}$ & $18-37$ & $18-37$ & $49-62 \times 17-40$ & $20-50 \times 18-39$ & $20-40$ & - \\
\hline $\begin{array}{l}\text { Phaeophycean or } \\
\text { colorless hairs, diam } \\
(\mu \mathrm{m})\end{array}$ & $8-10$ & $8-10$ & $8-10$ & - & $8-10$ & $8-10$ \\
\hline
\end{tabular}

